\title{
Characterization of an Unusual and Complex Chromosome 21 Rearrangement Using Somatic Cell Genetics and Cloned DNA Probes
}

\author{
Margaret L. Van Keuren, Gordon D. Stewart, Cynthia M. Bradley, David M. Kurnit, Rachael L. Neve, \\ Paul C. Watkins, Rudolph E. Tanzi, James F. Gusella, and David Patterson \\ Department of Pediatrics and Communicable Diseases, University of Michigan and Howard Hughes Medical Institute \\ (M.L.V., G.D.S., D.M.K.) and Department of Human Genetics, University of Michigan Medical Center, \\ Ann Arbor, Michigan (D.M.K.); Cytogenetics Laboratory, Children's Hospital and Medical Center, Seattle (C.M.B.); Genetics \\ Division, The Children's Hospital, (R.L.N.) and Neurogenetics Laboratory, Massachusetts General Hospital and \\ Department of Genetics, Harvard Medical School, Boston (R.E.T., J.F.G.); Integrated Genetics, Inc., \\ Framingham, Massachusetts (P.C.W.); The Eleanor Roosevelt Institute for Cancer Research and Departments of \\ Biochemistry, Biophysics and Chemistry, and of Medicine, University of Colorado Health Sciences Center, Denver (D.P.)
}

In a previous case of a newborn infant with typical Down syndrome, chromosome analysis indicated the presence of an unusual and complex translocation of chromosome 21 . The patient's cells contained one normal chromosome 21 and a rearranged, $F$ group-sized submetacentric chromosome. This abnormal chromosome appeared to involve duplication of the distal portion of $21 \mathrm{q}$ with translocation to the short arm, and a deletion of C-band-positive centromeric heterochromatin. Using linearly ordered cloned DNA probes, we report the detailed molecular examination of this abnormal chromosome, which has been isolated on a hamster background in a hybrid cell line. Both short arm and pericentromeric sequences are present on this chromosome, as well as distal $21 \mathrm{q}$ sequences. However, a substantial portion of proximal $21 \mathrm{q}$ is deleted. The distal boundary of this deleted section can be pinpointed within the region between two loci (D21S8 and D21S54), a distance of about $5,000 \mathrm{~kb}$. This study illustrates the power of using precisely mapped, linearly ordered DNA probes to characterize this type of rearrangement. In addition, this hybrid cell line can also be used as a member of a mapping panel to map DNA sequences regionally on chromosome 21 .

Received for publication September 13, 1988; revision received February 17, 1989.

Address reprint requests to Margaret L. Van Keuren, Ph.D., Howard Hughes Medical Institute, 1150 W. Medical Center Dr., MSRB I, Room 3520, Ann Arbor, MI 48109-0650.
KEY WORDS: human chromosome 21, Down syndrome, somatic cell hybrids, trisomy 21

\section{INTRODUCTION}

Down syndrome most commonly results from trisomy 21. Few cases are due to translocation of all or a portion of $21 \mathrm{q}$ to another chromosome. Recently, an unusual and complex translocation chromosome 21 was described in a Down syndrome patient [Bradley et al., 1986]. Neonatally, the child presented with face and dermatoglyphics typical of Down syndrome. The child suddenly died at 7 months. Chromosome analysis of lymphocytes, fibroblasts, and other tissue demonstrated mosaicism for two cell lineages. One cell line was a $46, \mathrm{XX},-21,+\mathrm{t}(21 ; 21)$ containing a structurally abnormal submetacentric chromosome thought to represent a non-Robertsonian translocation. The other cell line, comprising about $50 \%$ of cells examined, had the same abnormal chromosome and an additional small dot-like marker chromosome. The proposita's mother and sister, both phenotypically normal, had 47 chromosomes, with an extra bisatellited marker in addition to the normal chromosomes. The father and two maternal aunts had normal chromosomes.

The abnormal submetacentric chromosome in the proposita is the size of an $F$ chromosome and appears to be the result of a non-Robertsonian translocation involving two chromosome 21s. The centromere appears to be less constricted than in other chromosomes, and CBG banding did not detect centromeric constitutive heterochromatin. Although the exact breakpoints involved in the translocation are indeterminate by cytogenetics, it appears that distal $21 q$ is duplicated as evidenced by distinctive R-bands (by RFA technique) on both ends of the abnormal chromosome. The chromosome is interpreted to be a duplication of the distal portion of $21 \mathrm{q}$, including 
band 21q22, translocated to the short arm. C-band-positive centromeric heterochromatin is deleted. However, since the chromosome was stable and present in every cell examined, it presumably has a functional centromere. The proposita's fibroblasts demonstrated a gene dosage effect for the enzyme GARS (phosphoribosylglycineamide synthetase), which maps to 21q22.1 [Moore et al., 1977; Chadefaux et al., 1984]. This is consistent with a duplication of the region of chromosome 21 containing the gene.

The small bisatellited marker found in the mother and sister was present in all cells examined. C-banding showed that it has a large heterochromatic region. It is unclear if the proposita's $t(21 ; 21)$ chromosome was derived from the same event that produced this bisatellited marker. A partial karyotype of the translocation chromosome and the bisatellited marker is shown in Figure 1.

Bradley et al. [1986] also reported the production of a Chinese hamster ovary (CHO) hybrid cell line that contains the proposita's abnormal translocation chromosome as the only human chromosome. Isozyme analysis demonstrated that this hybrid cell line expressed human SOD-1 (superoxide dismutase, soluble form), a chromosome 21-encoded gene mapped to 21q22.1 [Sinet et al., 1976], in addition to hamster SOD-1. The hybrid cells also displayed human GARS activity.

We have extended the analysis of the hybrid cell line containing this unusual chromosome with the use of molecular probes whose subregional chromosome location and/or linkage order is known.

\section{MATERIALS AND METHODS Cell Lines}

The cell line ACEM2-90 was derived by fusing fibroblasts from the proposita with the Chinese hamster ovary (CHO-K1) cell line mutant $\mathrm{Ade}^{-} \mathrm{C}$. $\mathrm{Ade}^{-} \mathrm{C}$ is deficient in GARS activity (E.C.6.3.4.13) and requires exogenous purines for growth [Oates and Patterson, 1977]. The human GARS gene is located on chromosome 21 [Moore et al., 1977], in band q22.1 [Chadefaux et al., 1984]. ACEM290 was grown in Ham's F12D medium [Kao and Puck, 1974] with $7 \%(\mathrm{v} / \mathrm{v})$ dialyzed fetal calf serum; this medium lacks purines, and therefore hybrid cells must retain the human GARS gene for growth. ACEM2-90 contains the proposita's unusual translocation chromosome as the only human chromosome. The derivation and characterization of this cell line are described elsewhere [Bradley et al., 1986].

\section{Cytogenetic Analysis}

The chromosome constitution of the ACEM2-90 cell hybrid was verified by cytogenetic analysis prior to DNA extraction. Following GTG banding [Seabright, 1971], selected metaphases were photographed, and the slides were destained in methanol/acetic acid 3:1 (v/v) and restained using the Giemsa-11 (G-11) technique [Alhadeff et al., 1977; Friend et al., 1976]. With G-11 staining, human chromosomes appear blue, while the CHO chromosomes appear magenta. The human chromosomes were then identified in the G-banded photographs.

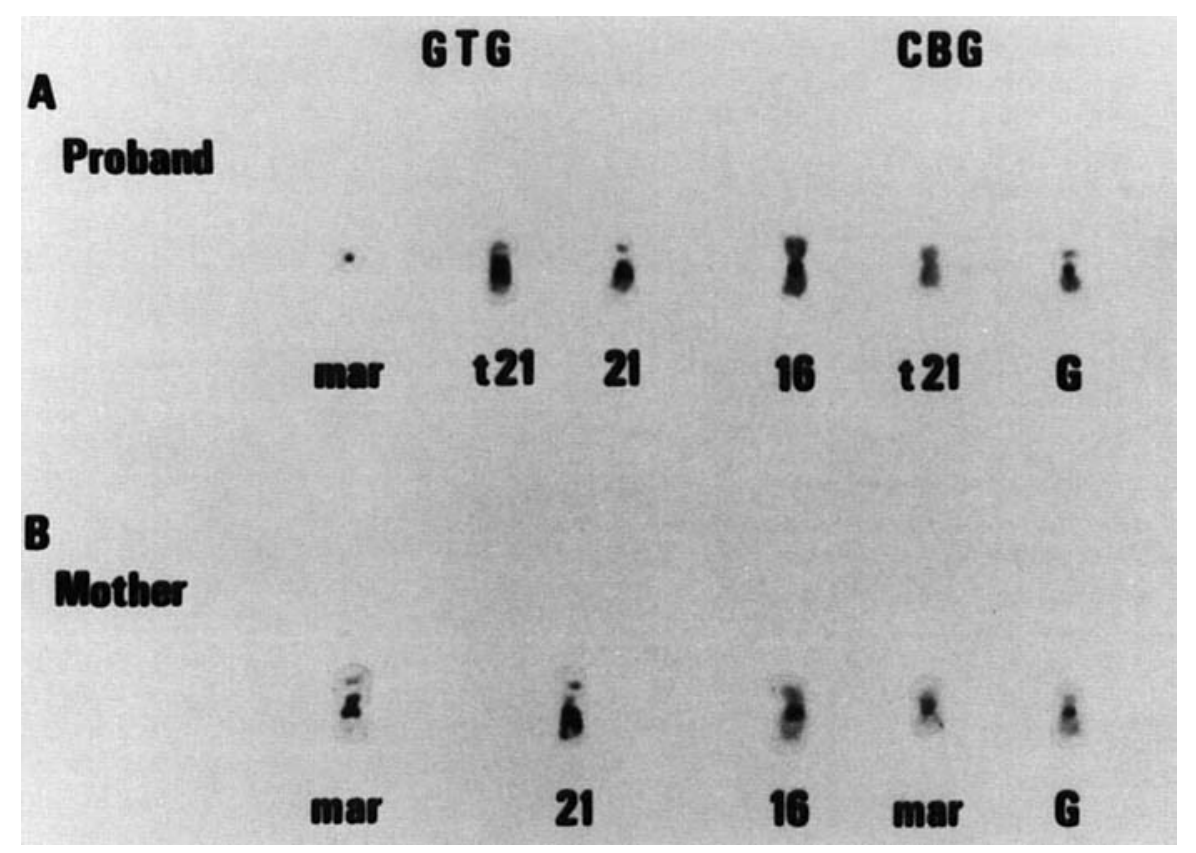

Fig. 1. A: Composite of cytogenetic results of the proposita showing GTG [Seabright, 1971] and CBG [Sumner, 1972] banding of dot-like marker (mar), normal 21 or G group, and abnormal translocation (t21). B: The bisatellited marker of the mother is shown with a normal 21 or $\mathrm{G}$ group, and with chromosome 16 for comparison of CBG banding of constitutive heterochromatin. 


\section{Molecular Probes}

The anonymous human DNA probes pPW235D, pPW 233F, pPW228C, pPW236B, pPW245D, pPW267C, pPW231C, pPW513-5H, pPW524-5P, pPW523-10B, and pPW520-10R have been described previously [Watkins et al., 1985a,b]. All map uniquely to chromosome 21, with the exception of pPW235D, which has related sequences on several other chromosomes. These probes have been mapped to the following locations: pPW235D-21p11.2; pPW233F, pPW228C, pPW236B, pPW245D, pPW267C, pPW513-5H, and pPW524-5P-21q (21q22.3 excluded); pPW523-10B and pPW231C-21q22.3; and pPW52010R-distal 21q22.3 [Van Keuren et al., 1986]. Recently more precise localization has been determined by in situ hybridization for pPW228C and pPW236B to 21q11.2 $\rightarrow$ $21 \mathrm{q} 21, \mathrm{pPW} 245 \mathrm{D}$ to $21 \mathrm{q} 21.1 \rightarrow 21 \mathrm{q} 22.11$, pPW513-5H to $21 \mathrm{q} 21.3 \rightarrow 21 \mathrm{q} 22.11$ [Münke et al., 1988], and for $\mathrm{pPW}$ $524-5 \mathrm{P}$ to $21 \mathrm{q} 21 \rightarrow 21 \mathrm{q} 22.1$ [Nakai et al., 1987].

The probe $\mathrm{C}_{\mathrm{HB}}$ (kindly provided by $\mathrm{R}$. Schmickel) is a cloned section of the human rRNA gene cluster [Erickson et al., 1981], which is located on the stalk of the short arm of the acrocentric chromosomes [Schmickel and Knoller, 1975]. Repetitive, human-specific, alphoid centromeric DNA probes used included p82H [Mitchell et al., 1985] (a gift from A. Mitchell) and Xba14 [Sylvester et al., 1985] (a gift from J. Sylvester).

pUNC724 is an Hela cDNA clone, which detects a loworder repeated family of DNA sequences [Kurnit et al., 1984] that map to the pericentromeric region of the acrocentric chromosomes. The ACEM2-90 hybrid was shown to contain DNA sequences detected by pUNC724, which localize to $21 \mathrm{p}$ regions above and below the ribosomal DNA locus [Kurnit et al., 1986].

The human DNA probe p21-4U is a single copy sequence related to the 724 family of sequences [Kurnit et al., 1984, 1986]. It localizes to $21 \mathrm{q} 11$ by in situ hybridization (unpublished data, U. Tantravahi and D. Kurnit). The cloned probes p21-7U and p21-5L were isolated from a cDNA library; p21-7U maps to 21q22.3, and p21-5L maps to $21 \mathrm{q} 22$ above the $21 \mathrm{q} 22.3$ band [Neve et al., 1986].

The anonymous DNA probes pGSM21, pGSE9, pGSH8, pGSE8, and pGSB3 are specific for human chromosome 21 [Stewart et al., 1985]. Their map locations are as follows: pGSM21, pGSE9-21q11.1 $\rightarrow 21$ q21; pGSH8proximal 21q22.3; pGSE8 and pGSB3-distal 21q22.3 [Stewart et al., 1985; Neve et al., 1986].

Some of these probes have been ordered by linkage analysis [Tanzi et al., 1988; Watkins et al., 1987] using restriction fragment length polymorphisms in a large Venezuelan kindred. The linear order, where known, is indicated in Table I.

\section{Southern Blot Analysis}

The presence or absence of DNA fragments detectable with the cloned DNA probes listed above was determined by Southern blot analysis. In each case, one or more positive controls were included. Various $\mathrm{CHO} \times$ human hybrid cells containing an intact chromosome 21 or $21 \mathrm{q}$

TABLE I. Results of Southern Blot Analysis of Cloned DNA Probes With ACEM2-90

\begin{tabular}{|c|c|c|c|}
\hline Probe name & $\begin{array}{c}\text { Lacus } \\
\text { symbol }\end{array}$ & $\begin{array}{l}\text { Present }(+) \text { or } \\
\text { absent }(-) \text { in } \\
\text { ACEM2-90 }\end{array}$ & $\begin{array}{c}\text { Chromosome } \\
\text { location }\end{array}$ \\
\hline pPW235D & D2155 & + & $21 \mathrm{p} 11.2$ \\
\hline $\mathrm{C}_{\mathrm{HB}}$ & & + & $21 \mathrm{p} 12$ \\
\hline pUNC724 & DNF19S4 & + & $21 \mathrm{p} 11.2 \rightarrow 21 \mathrm{p} 13$ \\
\hline Xbal4 & & + & $21 \mathrm{cen}$ \\
\hline p $82 \mathrm{H}$ & & + & 21cen \\
\hline $\mathrm{p} 21-7 \mathrm{U}$ & $\mathrm{D} 21 \mathrm{~S} 78$ & + & $21 \mathrm{q} 22.3$ \\
\hline $\mathrm{p} 215 \mathrm{~L}$ & D21S77 & - & $21 \mathrm{q} 11.1 \rightarrow 21 \mathrm{q} 22.2$ \\
\hline pPW267C & D21S12 & - & $21 \mathrm{q} 11.1 \rightarrow 21 \mathrm{q} 22.2$ \\
\hline \multicolumn{4}{|c|}{ Probes ordered by linkage in addition to physical analysis ${ }^{a}$} \\
\hline 1. pGSM21 & $\mathrm{D} 21 \mathrm{~S} 13$ & - & $21 \mathrm{q} 11.1 \rightarrow 21 \mathrm{q} 21.2$ \\
\hline $\mathrm{p} 21-4 \mathrm{U}$ & $\mathrm{D} 21 \mathrm{~S} 110$ & - & $21 \mathrm{q} 11$ \\
\hline 2. pGSE9 & $\mathrm{D} 21 \mathrm{~S} 16$ & - & $21 \mathrm{q} 11.1 \rightarrow 21 \mathrm{q} 21.2$ \\
\hline pPW233F & $\mathrm{D} 21 \mathrm{~S} 4$ & - & $21 \mathrm{q} 11.1 \rightarrow 21 \mathrm{q} 22.2$ \\
\hline 3. $\mathrm{pPW} 228 \mathrm{C}$ & D21S1. & - & $21 \mathrm{q} 11.2 \rightarrow 21 \mathrm{q} 21$ \\
\hline pPW236B & D21S11 & - & $21 \mathrm{q} 11.2 \rightarrow 21 \mathrm{q} 21$ \\
\hline 4. $\mathrm{pPW} 245 \mathrm{D}$ & $\mathrm{D} 21 \mathrm{~S} 8$ & - & $21 \mathrm{q} 21 \rightarrow 21 \mathrm{q} 22.11$ \\
\hline 5. pPW513-5H & D21S54 & + & $21 \mathrm{q} 22.13 \rightarrow 21 \mathrm{q} 22.11$ \\
\hline 6. SOD1 & & + & $21 \mathrm{q} 22.1$ \\
\hline 7. pPW524-5P & D21S58 & + & $21 \mathrm{q} 21 \rightarrow 21 \mathrm{q} 22.1$ \\
\hline 8. pGSH 8 & D21S17 & + & $21 \mathrm{q} 22.3$ \\
\hline 9. pPW523-10B & D21S57 & + & $21 \mathrm{q} 22.3$ \\
\hline 10. pPW231C & $\mathrm{D} 21 \mathrm{~S} 53$ & + & $21 \mathrm{q} 22.3$ \\
\hline 11. pGSE8 & D21S15 & + & $21 \mathrm{q} 22.3$ \\
\hline 12. pGSB3 & D21S19 & + & $21 \mathrm{q} 22.3$ \\
\hline 13. pPW520-10R & D21S56 & + & $21 \mathrm{q}^{2} 2.3$ \\
\hline
\end{tabular}

${ }^{a}$ The order of the two probes each listed in Nos. 1-3 has not been determined by linkage analysis. 
as the only human chromosome material were used for this purpose; these control hybrids are described in Van Keuren et al. [1986]. High molecular weight DNA was prepared from ACEM2-90 and control cells as described [Gusella et al., 1979]. DNA was digested to completion with the restriction enzyme appropriate for each probe, separated by agarose gel electrophoresis, and transferred to nitrocellulose as described [Southern, 1975]. Cloned probes were nick-translated [Rigby et al., 1977] with ${ }^{32} \mathrm{P}$ and hybridized to the nitrocellulose-bound DNA at $42^{\circ} \mathrm{C}$ with $50 \%$ formamide. Nitrocellulose filters were washed as described [Drabkin et al., 1985], dried and exposed to Kodak XAR X-ray film. In some cases, labeling was done by oligodeoxynucleotide priming [Feinberg and Vogelstein, 1983], and DNA was transferred to Genatran nylon membrane (Plasco, Woburn, MA) as described [Neve et al., 1986].

\section{RESULTS AND DISCUSSION}

Cytogenetic analysis confirmed the proposita's unusual translocation chromosome as the only human chromosome in ACEM2-90 hybrid cells. A metaphase spread of ACEM2-90 is shown in Figure 2. 'The human $t(21 ; 21)$ was present in $100 \%$ of cells examined, an expected result because of the purine prototropy selection system uti- lized. It was previously hypothesized on the basis of cytogenetic analysis that this chromosome contains a duplication of a distal section of $21 \mathrm{q}$, including all or most of band $21 q 22$ translocated onto $21 p$, with deletion of centromeric heterochromatin.

The presence or absence of cloned DNA probes in ACEM2-90 was determined by Southern blot analysis (Table I). These data give insight into the composition of the complex, rearranged $t(21 ; 21)$ chromosome, which is the apparent cause of Down syndrome in the proposita. This chromosome appears to contain a substantial part, if not all, of $21 \mathrm{p}$. Human rRNA sequences are present even though the translocation chromosome was NORnegative by silver staining in the patient's cells [Bradley et al., 1986]. Moreover, the chromosome does contain centromeric material as indicated by the presence of DNA sequences homologous to $\mathrm{Xba14}$ and $\mathrm{p} 82 \mathrm{H}$. It is likely that the $t(21 ; 21)$ has a functional centromere since the chromosome appears to be present in all cells of the proposita examined, and since it appears to distribute to both daughter cells during mitosis in the ACEM2-90 hybrid. Nonetheless, the centromere in this chromosome may not be entirely normal, since we have observed a tendency for the chromosome to be lost from or to rearrange in hybrid cells. Cytogenetic analysis [Bradley

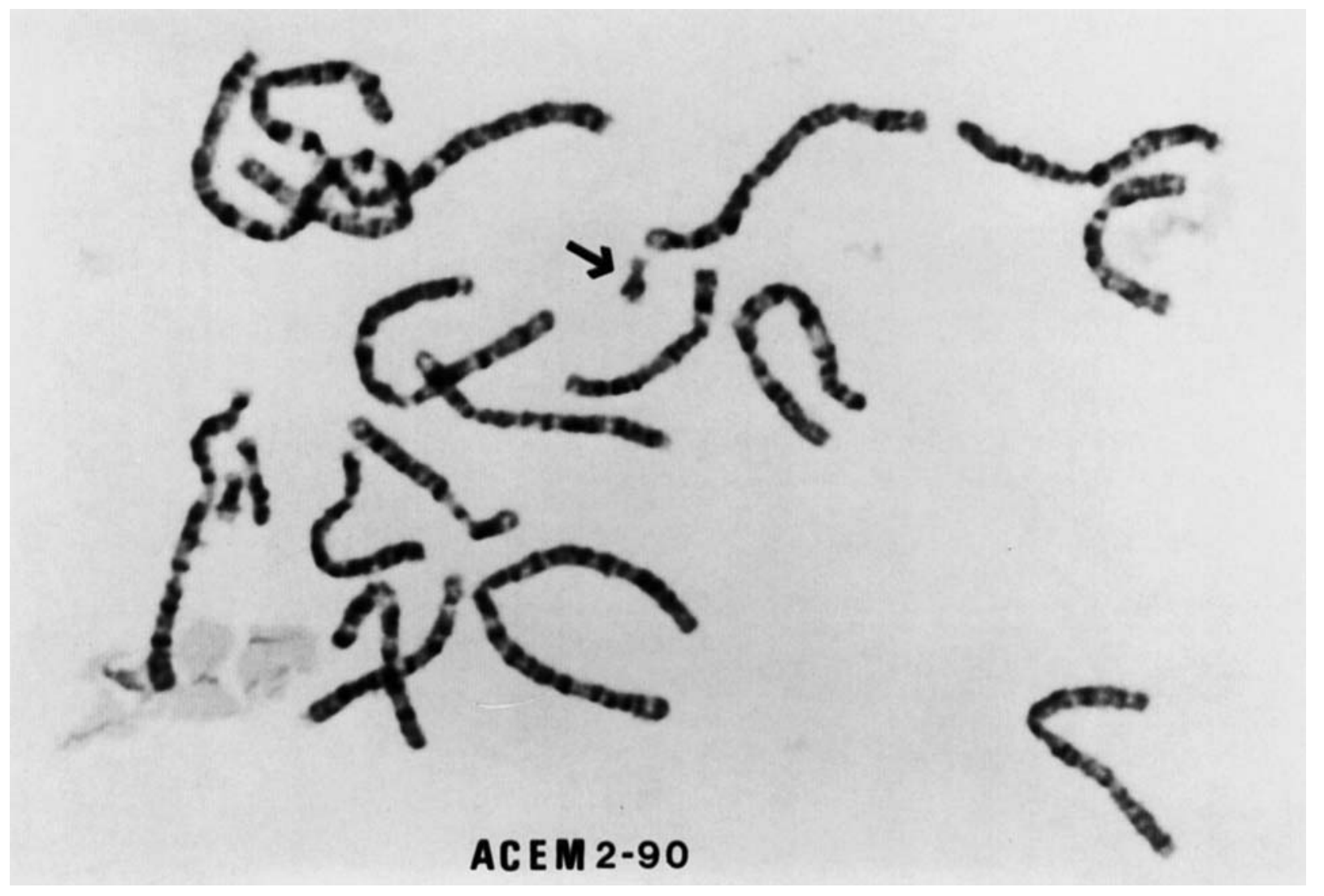

Fig. 2. GTG banding of the CHO $\times$ human hybrid ACEM2-90. The arrow indicates the only chromosome that stained blue with subsequent
G-11 staining, indicating its human origin. This cell line carries the $t(21 ; 21)$ as the only human chromosome. 


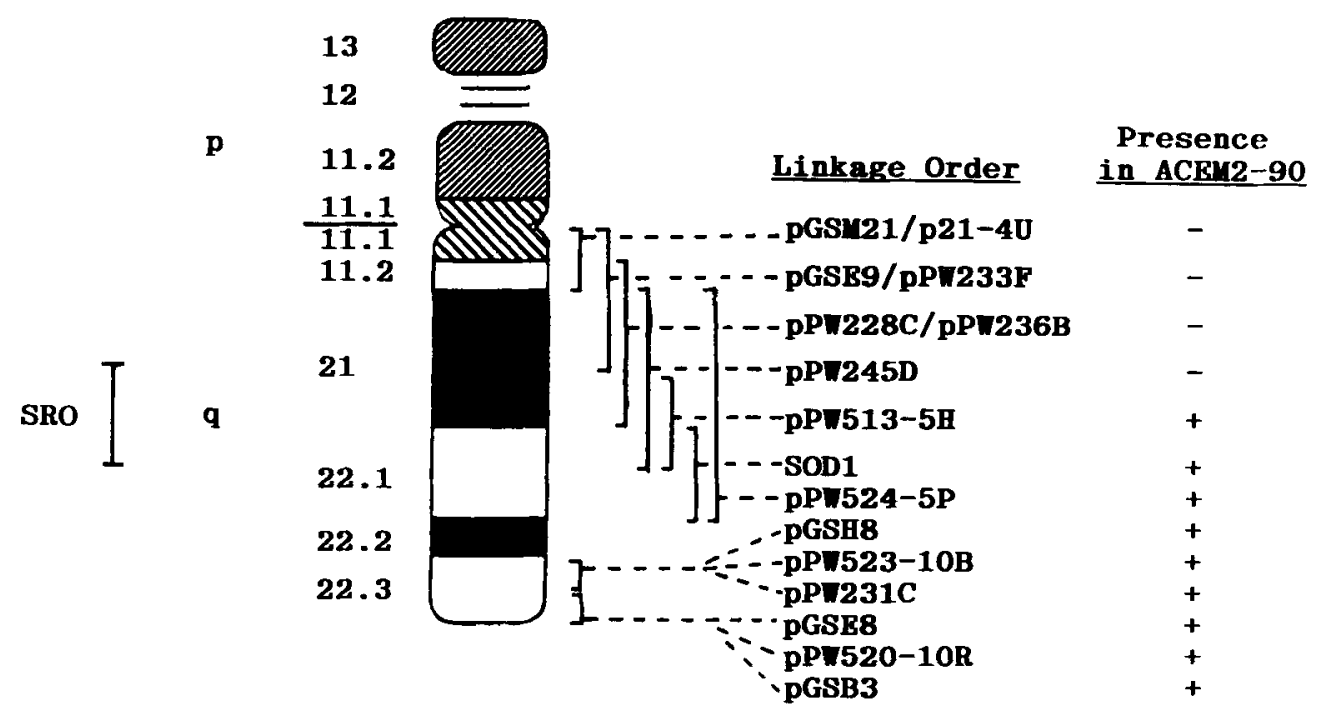

Fig. 3. Schematic representation of human chromosome 21 with physical location of the DNA probes, which have been ordered by linkage analysis and their presence $(+)$ or absence $(-)$ in the ACEM2-90 hybrid cell line. Also indicated is the smallest region of overlap (SRO) for the distal breakpoint area that can be determined from the physical map of these probes.

et al., 1986] provides further evidence of the centromere's abnormal nature as indicated by the lack of $\mathrm{C}$-banding.

It appears that a contiguous section of proximal $21 \mathrm{q}$ (linked probes $1-4$, Table I) is deleted in this chromosome. This section extends down through all or most of band 21q21. A contiguous section of distal 21q, including all or most of $21 \mathrm{q} 22$, appears to be present in this chromosome (linked probes 5-11, Table I). Figure 3 depicts these results.

The hypothesized loss of heterochromatin material proximal to the centromere on the long arm of the chromosome that was indicated by cytogenetic analysis is supported by our data. As yet, we have been unable to confirm deletion of any short arm material from this abnormal chromosome. The presence of a large fraction of the region of chromosome 21 , namely band q22, previously shown to be significant for the development of Down syndrome [Niebuhr, 1974; Williams et al., 1975] is also confirmed. Previously it was only possible to show the presence of human superoxide dismutase and human GARS on this chromosome [Bradley et al., 1986]. We demonstrate here the presence of the pathogenetic region of chromosome 21 on this unusual chromosome, consistent with the hypothesized structure of the chromosome gathered from cytogenetic data alone [Bradley et al., 1986]. The combination of somatic cell genetic, classical genetic, cytogenetic, and molecular genetic techniques provides a robust approach for analysis of complex chromosomal rearrangements. We conclude that the $21 \mathrm{q}$ breakpoint at the distal boundary of the deleted section must lie between loci identified by the probes pPW245D and pPW513-5H, a segment that is proximal to the SOD1 locus. These probes are tightly linked $(\theta=0.04, \mathrm{z}=6.60$, P.C. Watkins, unpublished) and therefore confine the breakpoint to a narrow region of chromosome 21 , on the

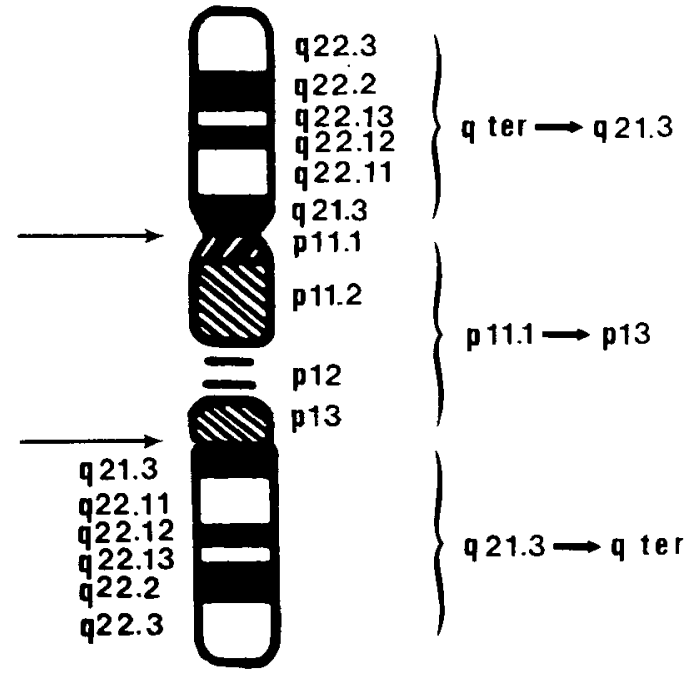

Fig. 4. A proposed schematic diagram of the abnormal chromosome in the proposita, designed to fit the cytogenetics and molecular evidence described herein. The breakpoints (indicated by arrows) may be anywhere between $\mathrm{q} 21.2$ and halfway down band q22.1 and are possibly different in the two segments.

order of around $5,000 \mathrm{~kb}$. We propose that based on cytogenetic and molecular evidence described herein, the rearranged chromosome can be described as 21(qter $\rightarrow$ 21.3 or q22.1::p11 $\rightarrow$ p13::q21.3 or q22.1 $\rightarrow$ qter) (Fig. 4 ).

Because a number of the DNA probes used in this study detect restriction fragment length polymorphisms (RFLPs), it is possible to gain further insight into the mechanism by which this complex rearrangement may 
have occurred. Assuming that the distal $21 q$ section present on the $t(21 ; 21)$ is duplicated, it is possible to calculate the odds in favor of this duplicated area originating from only one chromosome 21 homologue, rather than both, during the rearranging event. A preliminary examination was made with some of the $21 q$ probes for which sequences were detected in the ACEM2-90 hybrid. In each case, no heterozygosity was detected by Southern blot analysis. As shown by Table II, the random probability of homozygosity for each of the six alleles examined is $4.2 \%$. Therefore, if the distance covered by these loci is indeed duplicated in the $t(21 ; 21)$, it is $95.8 \%$ certain that only one chromosome 21 homologue was involved in the rearrangement. Further information could be gained if DNA samples from the parents of the child were examined and found to possess different alleles of the polymorphic probes used in this study.

These results do not demonstrate whether this abnormal chromosome in fact contains two copies of the $21 \mathrm{q} 22 \rightarrow 21 \mathrm{qter}$ region of chromosome 21 , nor do they give a clear indication about the nature of the bisatellited marker chromosome observed in the mother and sib of the proposita. Nevertheless, certain predictions regarding these points can be made and tested experimentally on the basis of the data presented here. First, we would predict that in situ hybridization analysis to metaphase chromosomes of the ACEM2-90 hybrid should reveal the presence of two copies of at least some of the 21q22specific probes used in this study, one at each end of the ACEM2-90 human chromosome. Similarly, we predict that short arm probes and centromere probes appear only in the short arm and pericentromeric region of this abnormal chromosome. Finally, we should be able to examine by in situ hybridization to metaphase chromosomes whether the bisatellited marker chromosome observed in the mother and sib of this patient indeed contains chromosome 21-specific sequences not found on the chromosome in the ACEM2-90 hybrid. It might even be possible to determine whether these DNA sequences have been duplicated in this marker chromosome. This would unambiguously determine whether the marker chromosome is indeed derived from chromosome 21. These studies coupled with additional studies with different chromosome 21 DNA-specific sequences as they

TABLE II. Chromosome 21 DNA Probes Used to Test Homozygosity of the $t(21 ; 21)$ in ACEM2-90 Hybrid*

\begin{tabular}{lccc}
\hline DNA probe & Enzyme & $\begin{array}{c}\text { Minor allele } \\
\text { frequency }^{\text {a }}\end{array}$ & $\begin{array}{c}\text { Probability of } \\
\text { homozygosity }^{b}\end{array}$ \\
\hline pPW524-5P & PstI & 0.46 & .50 \\
pGSH8 & Bg1II & 0.43 & .51 \\
pPW231F & TaqI & 0.10 & .82 \\
pGSE8 & MspI & 0.46 & .50 \\
pGSB3 & PstI & 0.20 & .80 \\
pPW520-10R & ApaI & 0.50 & .50 \\
\hline
\end{tabular}

* Random probability of homozygosity at each allele equals $(.50)(.51)(.82)(.50)(.80)(.50)=.042$, or $4.2 \%$

${ }^{3}$ Human Gene Mapping 9 [1987]

Probability of homozygosity $=1$ - probability of heterozygosity, and probability of heterozygosity $=2 p q$, where $p$ and $q$ represent major and minor allele frequencies, respectively. become available should give us an unprecedented understanding of how this chromosome rearrangement may have taken place in this family.

\section{ACKNOWLEDGMENTS}

This work was supported by grants HD17449, HD06470, and HD20118 from NIH. We thank J. Sylvester and R. Schmickel for the $\mathrm{C}_{\mathrm{HB}}$ and Xba14 probes and A. Mitchell for $\mathrm{p} 82 \mathrm{H}$. This is contribution number 683 from the Eleanor Roosevelt Institute for Cancer Research. D.M.K. is an investigator, M.L.V. is a senior associate, and G.D.S. is an associate in the Howard Hughes Medical Institute.

\section{REFERENCES}

Alhadeff B, Velivasakis M, Siniscalco M (1977): Simultaneous identification of chromatid replication of human chromosomes in metaphases of man-mouse somatic cell hybrids. Cytogenet Cell Genet 19:236-239.

Bradley CM, Patterson D, Robinson A (1986): Somatic cell genetic studies on a family with Down syndrome due to an unusual translocation (21q21 $\rightarrow 21 \mathrm{qter}$ ). Trisomy 21 1:41-52.

Chadefaux B, Allard O, Rethoré MO, Raoul O, Poissonier M, Gilgenkrantz S, Cheruy C, Jerome $H$ (1984): Assignment of human phosphoribosylglycinamide synthetase locus to region $21 \mathrm{q} 22.1$. Hum Genet 66:190-192.

Drabkin HA, Diaz M, Bradley CM, LeBeau MM, Rowley JD, Patterson $D$ (1985): Isolation and analysis of the $21 \mathrm{q}+$ chromosome in the acute myelogenous leukemia 8;21 translocation: Evidence that c-mos is not translocated. Proc Natl Acad Sci USA 82:464-468.

Erickson JM, Rushford CL, Dorney DJ, Wilson GN, Schmickel RD (1981): Structure and variation of human ribosomal DNA: Molecular analysis of cloned fragments. Gene 16:1-9.

Feinberg AP, Vogelstein B (1983): A technique for radiolabeling DNA restriction endonuclease fragments to high specific activity. Anal Biochem 132:6-13.

Friend KK, Chen S, Ruddle FH (1976): Differential staining of interspecific chromosomes in somatic cell hybrids by alkaline giemsa stain. Somatic Cell Mol Genet 2:183-188.

Gusella J, Varsanyi-Breiner A, Kao F-T, Jones C, Puck TT, Keys C, Orkin S, Housman D (1979): Precise localization of human $\beta$-globin gene complex on chromosome 11. Proc Natl Acad Sci USA 76:52395243 .

Human Gene Mapping 9 (1987): Ninth International Workshop on Human Gene Mapping. Cytogenet Cell Genet 46(1-4):492, 493.

Kao F-T, Puck TT (1974): Induction and isolation of auxotrophic mutants in mammalian cells. In Prescott DM (ed): "Methods in Cell Biology," 8th ed. New York: Academic Press, pp 23-39.

Kurnit DM, Neve RL, Morton CC, Bruns GAP, Ma NSF, Cox DR, Klinger HP (1984): Recent evolution of DNA sequence homology in the pericentromeric regions of human acrocentric chromosomes. Cytogenetic Cell Genet 38:99-105.

Kurnit DM, Roy S, Stewart GD, Schwedock J, Neve RL, Bruns GAP, Van Keuren ML, Patterson D (1986): The 724 family of DNA sequences is interspersed about the pericentromeric regions of human acrocentric chromosomes. Cytogenet Cell Genet 43:109-116.

Mitchell AR, Gosden JR, Miller DA (1985): A cloned sequence, p82H, of the alphoid repeated DNA family found at the centromeres of all human chromosomes. Chromosoma 92:369-377.

Moore EE, Jones C, Kao F-T, Oates DA (1977): Synteny between glycineamide ribonucleotide synthetase and superoxide dismutase (soluble). Am J Hum Genet 29:389-396.

Münke M, Foellmer B, Watkins PC, Cowan JM, Carrol AJ, Gusella JF, Francke U (1988): Regional assignment of six polymorphic DNA sequences on chromosome 21 by in situ hybridization to normal and rearranged chromosomes. Am J Hum Genet 42:542-549.

Nakai H, Byers MG, Watkins PC, Shows TB (1987): Localization of nine DNA segments detecting RFLPs on chromosome 21q. Cytogenet Cell Genet 46:667. 
Neve RL, Stewart GD, Newcomb P, Van Keuren ML, Patterson D Drabkin HA, Kurnit DM (1986): Human chromosome 21-encoded cDNA clones. Gene 49:361-369.

Niebuhr $\mathbf{E}$ (1974): Down's syndrome: The possibility of a pathogenetic segment on chromosome no. 21. Humangenetik 21:99-101.

Oates DC, Patterson D (1977): Biochemical genetics of Chinese hamster cell mutants with deviant purine metabolism: Characterization of Chinese hamster cell mutants defective in phosphoribosylpyrophosphate amidotransferase and phosphoribosylglycineamide synthetase and an examination of alternatives to the first step of purine biosynthesis. Somatic Cell Mol Genet 3:561-577.

Rigby PWJ, Diekmann M, Rhodes C, Berg P (1977): Labeling deoxyribonucleic acid to a high specific activity in vitro by nick translation with DNA polymerase I. J Mol Biol 113:237-251.

Schmickel RD, Knoller M (1975): Characterization and location of the human genes for ribosomal ribonucleic acid. Pediatr Res 11:929-935.

Seabright M (1971): A rapid banding technique for human chromosomes. Lancet 2:971, 972.

Sinet P-M, Couturier J, Dutrillaux B, Poissonier M, Raoul O, Rethore M-O, Lejeune J, Jerome H (1976): Trisomie 21 et superoxide dismutase-1 (IPO-A): Tentative de localisation sur la sous bande 21q22.1. Exp Cell Res 97:47-55.

Southern EM (1975): Detection of specific sequences among DNA fragments transferred to nitrocellulose. J Mol Biol 98:503-517.

Stewart GD, Harris P, Galt J, Ferguson-Smith MA (1985): Cloned DNA probes regionally mapped to human chromosome 21 and their use in determining the origin of nondisjunction. Nucleic Acids Res $13: 4125-4132$
Sumner AT (1972): A simple technique for demonstrating centromeric heterochromatin. Exp Cell Res 75:304-306.

Sylvester JE, Rosenstein R, Gorski J, Emanuel B, Schmickel RD (1985): Organization and distribution of the highly repetitive Xbal family of human DNA sequences. Am J Hum Genet 36:154S.

Tanzi RE, Haines JL, Stewart GD, Watkins PC, Gibbons KT, Faryniarz AG, Wallace MR, Hallewel R, Yount E, Wexler NS, Conneally PM, Gusella JF (1988): Genetic linkage map for the long arm of human chromosome 21. Genomics 3:129-136.

Van Keuren ML, Watkins PC, Drabkin HA, Jabs EW, Gusella JF, Patterson D (1986): Regional localization of DNA sequences on chromosome 21 using somatic cell hybrids. Am J Hum Genet 38:793804.

Watkins PC, Tanzi RE, Gibbons KT, Tricoli JV, Landes G, Eddy R, Shows TB, Gusella JF (1985a): Isolation of polymorphic DNA segments from chromosome 21. Nucleic Acids Res 13:6075-6088.

Watkins PC, Tanzi RE, Roy J, Stuart N, Stanislovitis P, Gusella F (1987): A cosmid genetic linkage map of chromosome 21 and localization of the breast cancer estrogen-inducible (BCEI) gene. Cytogenet Cell Genet 46:712.

Watkins PC, Watkins PA, Hoffman N, Stanislovitis P (1985b): Isolation of single-copy probes detecting DNA polymorphisms from a cosmid library of chromosome 21. Cytogenet Cell Genet 40:773.

Williams J, Summitt RL, Martens PR, Kimbrell RA (1975): Familial Down syndrome due to $t(10 ; 21)$ translocation: Evidence that the Down phenotype is related to trisomy of a specific segment of chromosome 21. Am J Hum Genet 27:478-485. 